\title{
HEDONIC AND QUALITY ANALYSIS OF CHIFFON CAKE WITH PURPLE SWEET POTATO FLOUR SUBSTITUTION
}

\author{
Tuatul Mahfud ${ }^{1 *}$ and Bambang Jati $\mathbf{K}^{\mathbf{2}}$ \\ ${ }^{1,2}$ Dept of Food and Beverage, State Polytechnic of Balikpapan \\ e-mail : tuatul.mahfud@poltekba.ac.id
}

\begin{abstract}
The purpose of this study is (1) to determine differences in color chiffon cake which is substituted with purple sweet potato flour in $50 \%, 75 \%$, and $100 \%$ of wheat flour; (2) to determine differences in flavor of chiffon cake which is substituted with purple sweet potato flour in $50 \%, 75 \%$, and $100 \%$ of wheat flour; (3) to determine differences in texture of chiffon cake which is substituted with purple sweet potato flour in $50 \%$, $75 \%$, and $100 \%$ of wheat flour; (4) to determine the level of consumer preferences to color of chiffon cake which is substituted with purple sweet potato flour in $50 \%, 75 \%$, and $100 \%$ of wheat flour; (5) to determine the level of consumer preferences on taste of chiffon cake which is substituted with purple sweet potato flour in $50 \%, 75 \%$, and $100 \%$ of wheat flour; (6) to determine the level of consumer preferences on the texture of chiffon cake which is substituted with purple sweet potato flour in $50 \%, 75 \%$, and $100 \%$ of wheat flour. In this research, there are two stages of research, the first phase of preliminary studies using a type of experimental research and the second phase of research using organoleptic research approach. The population in this study is the purple sweet potato in Balikpapan and the sample used is purple sweet potato with a weight of $5 \mathrm{~kg}$. Panelists were selected is a trained panel (semi-trained panel), which amounted to 25 skilled panelists. These skilled panelists are the student of Food and Beverage department in State Polytechnic of Balikpapan. Distribution of questionnaires to hedonic test and quality are done in one repetition. Data Analysis used is statistical inferential and one way ANOVE analysis using the SPSS 20.0 For Windows to see the level of preference of panelists and the hedonic quality of chiffon cake with the substitution of purple sweet potato in $50 \%, 75 \%$, and $100 \%$ of the flour that includes aspects of taste, color and texture. The results showed that (1) there is a difference of color in chiffon cake which is substituted with purple sweet potato flour in $50 \%, 75 \%$, and $100 \%$ from wheat flour; (2) there is a difference of taste in chiffon cake which is substituted with purple sweet potato flour in $50 \%, 75 \%$, and $100 \%$ from wheat flour; (3) there is a differences of texture in chiffon cake which is substituted with purple sweet potato flour in 50\%, 75\%, and 100\% from wheat flour; (4) The panelists liked the color of chiffon cake with purple sweet potato flour substitution in $100 \%$ from wheat flour; (5) panelists liked the flavor of chiffon cake with purple sweet potato flour substitution in $100 \%$ from wheat flour; (6) panelists liked the texture of chiffon cake with purple sweet potato flour substitution in $50 \%$ from wheat flour.
\end{abstract}

Keywords: purple sweet potato chiffon cake, hedonic, hedonic quality

\section{Introduction}

Industrial development of the national flour industry in Indonesia until 2014 reached 29 Flour Mills with details 25 Flour Mills focused on the Java and 4 Flour Mills out of Java. Beside that, the national consumption of wheat flour tends to increase every year. Start from 2013 the consumption of wheat flour in Indonesia reached 5.4 metric tons $(\mathrm{mt})$ and in 2014 reached $2.8 \mathrm{mt}^{[1]}$. That increase is due to the increasing demand of industry such as instant noodles, wet noodles, dried noodles and biscuits, and also the bakery industry. The product is generally use wheat flour as a raw material. That requirement that led to the import of wheat flour more increase because wheat flour (wheat) can not be cultivated in Indonesia which has a tropical region.

Based on the analysis above it is needed an alternative material that can reduce reliance on the use of wheat flour. 
One thing that can we do now is to introduce the abundant natural potential in Indonesia but not fully used such as tubers. Reasoning of this choice because of the tubers easy to be cultivated in Indonesia and relatively have a lower price. One of tubers that can be used is purple sweet potato.

Purple sweet potato contain anthocyanin substances which is quite high if it compared with other sweet potato that function as anti-cancer, anti-bacterial protection against liver damage, heart disease and stroke. Therefore the use of purple sweet potato is proper. The content of anthocyanins in purple sweet potato can also be used as a natural coloring agent in food $^{[2]}$. Currently the purple sweet potato has been cultivated for the market as a healthy food ${ }^{[3]}$. This is corroborated by Suda, et $\mathrm{al}^{[4]}$ even in Japan potato tubers of this type has been developed and utilized in commercial products in the form of natural dyes, purple pasta, and flour.

In addition, the use of purple sweet potato not only as an alternative to wheat flour, but also as an effort to build local food endurance. Food endurance is very important to establish the quality of Indonesian people, independent, and prosperous through the realization of the availability of adequate food, safe, quality, nutritious, varied and spread equally throughout Indonesia and also affordable by the community. According to Tuti Soenardi ${ }^{[5]}$ one of the efforts to build food endurance through diversification of local food. Potential food resources to encourage the diversification of food in terms of production and availability of food is still quite open because there are still a lot of land that could be addressed to develop the production other than rice.

Besides, the use of local potential such as tubers can increase the selling price of post-harvest results in its processing, so far the use of purple sweet potato is still fairly simple, mostly purple sweet potato is only consumed as a food additive of a mixture of fried or boiled. In addition, in our daily life has not been use as a product that has an economic value. So that these issues affect the shelf life of raw materials is quite short.

There are two phases in this research, the first phase is a preliminary study and the second phase is an advanced research. The preliminary study aims to determine the techniques and the proper formulation of chiffon cake product with purple sweet potato substitution. While further research is making chiffon cake that substituted with purple sweet potato in $50 \%, 75 \%$, and $100 \%$ of wheat flour. $25 \%$ interval of this research is to gain a clear and significant difference and knowing the organoleptic quality of chiffon cake produced. Organoleptic assessment includes the hedonic test and quality to determine the level of consumer preferences and quality of chiffon cake with purple sweet potato substitution.

\section{Research Methodology}

There are two phases of research, the first phase is preliminary studies using a type of experimental research and the second phase is an advanced studies using organoleptic approach. The population in this study is purple sweet potato in Balikpapan and the sample used is purple sweet potato with a weight of $5 \mathrm{~kg}$.

Panelists were selected is trained panel (semi-trained panel), they are 25 panelists who considered skilled in art. This trained panelists is student of Balikpapan State Polytechnic from food and beverage department. Distributing of questionnaires to hedonic test and quality in one repetition. Data analysis used is statistical inferential and one way ANOVA analysis using the SPSS 20.0 For Windows to see the level of preference of panelists and the hedonic quality of chiffon cake with the substitution of purple sweet potato in $50 \%, 75 \%$, and $100 \%$ of wheat 
flour that includes the aspects of taste, color and texture.

\section{Result and Discussion}

\subsection{Hedonic Quality Test of Color}

The score calculation of Hedonic quality test of chiffon cake color which is substituted with purple sweet potato in $50 \%, 75 \%$, and $100 \%$ of wheat flour using one way ANOVA test through the program SPSS 20.0 for windows indicate that there are differences in color on chiffon cake which is substituted with purple sweet potato in $50 \%, 75 \%$, and $100 \%$ of wheat flour. It is known from calculations of Fhit (3.90)> Ftab (3.12) at the $5 \%$ significance level.

The chiffon cake that is substituted with purple sweet potato in $100 \%$ of wheat flour or can be said as whole replacement of wheat flour into purple sweet potato has a color is closer to brown. That is because the substances of anthocyanin in purple sweet potato have color degradation due to heating in the drying process of purple sweet potato and chiffon cake oven process. Many forms of anthocyanin contained in purple sweet potato is cyanidin and peonidin. It is caused by heat treatment at anthocyanin substances can cause the balance of anthocyanin tend to colorless, it is carbinol and kalkon. Therefore more percentage of using purple sweet potato in chiffon cake processing makes the color of chiffon cake will be getting closer to a brown color.

\subsection{Hedonic Quality Test of Taste}

The score calculation of Hedonic quality test of chiffon cake taste which is substituted with purple sweet potato in $50 \%, 75 \%$, and $100 \%$ of wheat flour using one way ANOVA test through the program SPSS 20.0 for windows indicate that there is no difference of taste in chiffon cake that is substituted with purple sweet potato in $50 \%, 75 \%$, and $100 \%$ of wheat flour. It is known from calculations of Fhit (2.68) <Ftab (3.12) at the 5\% significance level.
Purple sweet potato substitution of $50 \%, 75 \%$, and $100 \%$ does not give significant difference of taste, all three substitutes are have the same taste. This is caused due to the influence of temperature when processing, according to Winarno ${ }^{[6]}$ who states that taste is influenced by several factors: chemical, temperature, concentration, and interaction with other flavor components. The use of high temperatures in processing of chiffon cake that includes heat treatment during drying of purple sweet potato and when oven process of chiffon cake at the end of treatment led to the inverse of sucrose into glucose and fructose so that the sweet taste of purple sweet potato is reduced and the percentage of purple sweet potato substitution that has different value of $25 \%$ can not provide a significant difference to the taste of chiffon cake.

\subsection{Hedonic Quality Test of Texture}

The score calculation of Hedonic quality test of chiffon cake texture which is substituted with purple sweet potato in $50 \%, 75 \%$, and $100 \%$ of wheat flour using one way ANOVA test through the program SPSS 20.0 for windows indicate that there are differences in texture of chiffon cake which is substituted with purple sweet potato in $50 \%, 75 \%$, and $100 \%$ of wheat flour. It is known from calculations of Fhit (4:06)> Ftab (3.12) at the $5 \%$ significance level.

Purple sweet potato substitution of $50 \%$ has the texture of soft chiffon cake with good pores if it compared with the substitution of $75 \%$ and $100 \%$. That is because of many purple sweet potato substitution would have an influence on the severity of chiffon and result in congested pores of chiffon.

\subsection{Hedonic Test of Color}

Based on the average value of purple sweet potato substitution in $50 \%$ of wheat flour to get the mean value in 3.28, which means the average panelist stated kind of like the color of chiffon cake with purple 
sweet potato substitution in $50 \%$ of wheat flour. The color of chiffon cake with purple sweet potato substitution in $75 \%$ of wheat flour obtained the mean value in 3.76. It shows that the panelists liked the color of chiffon cake purple sweet potato substitution in $75 \%$ of wheat flour. And the color of chiffon cake which substituted with purple sweet potato in $100 \%$ of wheat flour obtained the mean value in 4.00 . It shows that the panelists liked the color of chiffon cake which is substituted with purple sweet potato in $100 \%$ of wheat flour.

Based on the results of the total value (sum) that the highest values obtained in chiffon cake with purple sweet potato substitution in $100 \%$ of wheat flour which panelists expressed their Like in 100. It means that most panelists liked the color of chiffon cake with purple sweet potato substitution in $100 \%$ of wheat flour.

\subsection{Hedonic Test of Taste}

Based on the average value of purple sweet potato substitution in $50 \%$ of wheat flour to get the mean value in 3.76 , which means the average panelist stated kind of like the taste of chiffon cake with purple sweet potato substitution in $50 \%$ of wheat flour. The taste of chiffon cake with purple sweet potato substitution in $75 \%$ of wheat flour obtained the mean value in 3.56. It shows that the panelists liked the taste of chiffon cake purple sweet potato substitution in $75 \%$ of wheat flour. And the taste of chiffon cake which substituted with purple sweet potato in $100 \%$ of wheat flour obtained the mean value in 4.00. It shows that the panelists liked the taste of chiffon cake which is substituted with purple sweet potato in $100 \%$ of wheat flour.

Based on the results of the total value (sum) that the highest values obtained in chiffon cake with purple sweet potato substitution in $100 \%$ of wheat flour which panelists expressed their Like in 100. It means that most panelists liked the taste of chiffon cake with purple sweet potato substitution in $100 \%$ of wheat flour.

\subsection{Hedonic Test of Texture}

Based on the average value of purple sweet potato substitution in $50 \%$ of wheat flour to get the mean value in 4.16 , which means the average panelist stated kind of like the texture of chiffon cake with purple sweet potato substitution in $50 \%$ of wheat flour. The taste of chiffon cake with purple sweet potato substitution in $75 \%$ of wheat flour obtained the mean value in 3.16 . It shows that the panelists liked the texture of chiffon cake purple sweet potato substitution in $75 \%$ of wheat flour. And the texture of chiffon cake which substituted with purple sweet potato in $100 \%$ of wheat flour obtained the mean value in 3.84. It shows that the panelists liked the texture of chiffon cake which is substituted with purple sweet potato in $100 \%$ of wheat flour.

Based on the results of the total value (sum) that the highest values obtained in chiffon cake with purple sweet potato substitution in $50 \%$ of wheat flour which panelists expressed their like in 104. It means that most panelists liked the texture of chiffon cake with purple sweet potato substitution in $50 \%$ of wheat flour.

\section{Conclusion}

1. There are differences in color of chiffon cake which is substituted with purple sweet potato in $50 \%, 75 \%$, and $100 \%$ of wheat flour.a

2. There is a difference in taste of chiffon cake which is substituted with purple sweet potato in $50 \%, 75 \%$, and $100 \%$ of wheat flour.

3. There are differences in texture of chiffon cake which is substituted with purple sweet potato in $50 \%, 75 \%$, and $100 \%$ of wheat flour.

4. Panelists liked the color of chiffon cake with purple sweet potato substitution in $100 \%$ of wheat flour.

5. Panelists liked the flavor of chiffon cake with purple sweet potato substitution in $100 \%$ of wheat flour. 
6. Panelists liked the texture of chiffon cake with purple sweet potato substitution in $50 \%$ of wheat flour.

\section{Suggestion}

Further research is needed to analyze the nutrient content substitution chiffon cake with purple sweet potato.

\section{References}

[1] Aptindo. (2014). Overview tepung terigu nasional indonesia. Diakses pada tanggal 14 April 2015, di http://www.aptindo.or.id/pdfs/Update\%20o verview\%2011\%20Juli\%202014.pdf

[2] Montilla, Elyana. C., Hillebrand, Silke.,\& Winterhalter, Peter. (2011). Anthocyanins in Purple Sweet Potato (Ipomoea batatas L.)Varieties.Fruit, Vegertable, and Cereal Science and Biotechnology, 5, 19-24.

[3] Truong, V.D., Hu. Z., Thompson, R.L., et al. (2012). Pressurized liquid extraction and quantification of anthocyanins in purplefleshed sweet potato genotypes. Journal of Food Composition and Analysis, 26, 96103.

[4] Suda, I., Oki, T., Masuda, M., et al. (2003). Physiological functionality of purplefleshed sweet potatoes containing anthocyanins and their utilization in foods. Japan Agricultural Research Quarterly 37, 167-173.

[5] Tuti soenardi. (2002). Makanan Alternatif Untuk Ketahanan Pangan Nasional. Jakarta: Penerbit Buku Kompas.

[6] Winarno, F.G. (1997). Kimia Pangan dan Gizi. Jakarta: Gramedia Pustaka Utama. 